equipment is provided with a battery of tungstenfilament lamps, mounted on a suitable framework, for illuminating objects under water at ranges up to $20 \mathrm{ft}$. from the camera. In the course of the demonstration, the movements of a diver in a normal diving suit, and also of a 'frogman', could be seen in good detail on the television screen. Another important advantage of this method of examining objects on the sea-bed is that the television picture received on board ship from a submerged camera can be photographed and a permanent film-record thereby obtained. This aspect of the technique was illustrated in, for example, the "Television News Reel" shown a day or two after the demonstration.

\section{Rothamsted Manor House}

RothaMsted MANOR, the ancestral home of Sir John Bennet Lawes, founder of Rothamsted Experimental Station, has been converted into a hall of residence for members of Rothamsted staff and visiting scientific workers. The south front of this fine house was given its present shape in the seventeenth century; but the building has a history several hundreds of years older than this. The oldest portion of it, the present hall-originally a simple timberframed structure-dates back at least to the fourteenth or fifteenth century. Around this the owners during Elizabethan times built a typical Tudor country house, decorating some of the walls with mural paintings, one of which, depicting a siege (perhaps of Edinburgh in 1573), is still well preserved. In the 1630's Sir John Wittewronge, whose mother had bought the estate for him, took up residence there. His considerable additions and alterations left the house substantially as we see it to-day, and it remained in the possession of his descendants for three centuries. Sir John Bennet Lawes was born here on December 14, 1814. Some of his early experiments were made in one of the bedrooms, before he set up his first laboratory in a barn on the estate. $\mathrm{He}$ added the great drawing-room in 1863, to celebrate the coming-of-age of his son Charles, who in his turn built the single-story library beyond it. In 1934, after a public appeal which met with a very generous response not only in Great Britain but also in many other parts of the world, Rothamsted House and its estate of 527 acres were bought by the Lawes Agricultural Trust. The house remained a private residence until the Second World War, when it was taken over by the Army. Soon after its derequisition, work was begun on the conversion which has just been completed. Six small flats have been constructed at the east end of the main house, in the gatehouse and in the old brewhouse, and about twenty single rooms on the upper stories. Modern kitchens and a residents' dining-room have been built in the seventeenth-century kitchen wing, and barns and outhouses have been adapted to serve as a sample house, a museum and garages. The chief rooms of the main house, however, remain unaltered, and the amenities of the house and its garden have been carefully preserved.

\section{Journal of Rational Mechanics and Analysis}

Is January appeared the first number of a new journal, entitled Journal of Rational Mechanics and Analysis, edited by T. Y. Thomas and C. Truesdell, and published by the Graduate Institute for Applied Mathematics, Indiana University, Bloomington, Ind. The first number consists of 172 pages and contains the following papers: hydrodynamical existence theorems, by J. B. Serrin, jun.; deformation of sub-spaces in a Riemann space, by V. Hlavatý; elastic stress fields, by P. F. Nemónyi and W. Sáenz; statistical hydromechanics and functional calculus, by E. Hopf; and the mechanical foundations of elasticity and fluid dynamics, by C. Truesdell. Each volume will contain about six hundred pages, and usually one volume will appear each year. The subscription price is $\mathbf{1 8}$ dollars a volums; but a reduced rate of 6 dollars a volume is offered to those engaged in research or teaching. Subscriptions and inquiries should be addressed to the editors.

\section{Society for the Bibliography of Natural History}

Aт the annual general meeting of the Society for the Bibliography of Natural History, held in the British Museum (Natural History), on April 21, it was reported that a further part of the Society's Journal, containing several articles of a miscellaneous character, is in the press. After the conclusion of formal business, members visited the new library quarters of the Department of Entomology of the Museum, where they were received by the keeper, Mr. N. D. Riley; a small exhibition of books and original drawings of entomological interest had been prepared for the occasion. The following officers of the Society were elected : President, Dr. J. Ramsbottom; Honorary Secretary and Treasurer, A. C. Townsend, British Museum (Natural History), Cromwell Road, London, S.W.7 ; Committee, A. G. Davis, W. N. Edwards, Dr. F. C. Fraser, F. J. Griffin, W. T. Stearn and C. Kirke Swann.

\section{Graduate Science Fellowships of the U.S. National Science Foundation}

Tне National Science Foundation (2,144 California Street, N.W., Washington 25, D.C.) has recently announced that 624 graduate fellowships in the natural sciences for the academic year 1952-53 have been awarded, of which 569 were predoctoral and 55 postdoctoral fellowships. The successful candidates were chosen from among about three thousand applications drawn from all parts of the United States and its possessions and from United States citizens abroad, and the selection was carried out by the National Research Council, predoctoral applicants being required to take an examination. The distribution of the fellowships according to year since graduation is as follows : first year, 169 ; second year, 170 ; advanced predoctoral, 230 ; and postdoctoral, 55. The awards to first-year graduates represent a departure from the Foundation's previous policy and are designed to encourage students to take up work leading to advanced research. The largest group of fellowships, totalling 158, is for research in the biological sciences, and in other fields the numbers of awards are as follows : chemistry, 140 ; physics, 137 ; engineering, 75 ; mathematics, 62 ; earth sciences, 36 ; agriculture, 7 ; astronomy, 6 ; and anthropology, 3. Fellows may pursue their training at accredited non-profit institutions of higher education in the United States or similar institutions abroad approved by the Foundation. The value of the fellowships is as follows (in dollars a year) : first year, 1,400 ; second year, 1,600 ; advanced predoctoral, 1,700; and postdoctoral, 3,000. Second-year and higher fellows receive additional allowances for wives and children. Normal tuition and laboratory fees are paid by the Foundation, and limited allowances to aid in defraying costs of travel are provided. 